\title{
Dysfunctions in communication in business organizations in Southern Poland
}

M.A. Marek Makowiec University of Economics in Krakow Department of Organizational Behavior

Prof. Arkadiusz Potocki University of Economics in Krakow Department of Organizational Behavior

\section{Introduction}

Competitiveness of enterprises increasingly depends on information obtained in the process of communication which, at the enterprise level, can be considered as external communication (extending between the organization and its external environment) and internal (relating to the interaction between the members of the organization) (Stor 2002, pp. 295).

In the literature, we have a large number of publications dealing with communication functions in the organization. Regardless of the size of the company and the industry in which it operates, the main function of communication in organizations is to ensure integration with the surrounding environment and to support the smooth functioning of the cells and the positions within the company. Unfortunately, in the functioning of the economic and administrative institutions have place all kinds of dysfunctions and pathologies organization, which affect negatively on the process of communication, and at the same time directly translate to a significant deterioration of the results obtained by these entities. 
The aim of this study was to determine the main deficiencies and dysfunctions in communication processes in organizations which then have an impact on lowering the efficiency of this communication. In the following part of the study the authors demonstrated possible remedial and improvement actions which are intended in helping to minimize or even to eliminate anomalies diagnosed.

In the study the authors present the results of two empirical studies conducted in the years 2010 - 2013 on a group of 226 and 172 companies, mostly from the Southern Poland, through which it was possible, inter alia, to identify a variety of difficulties and dysfunctions in communication in Polish organizations in the South during the crisis. The second aspect concerns the study of dysfunction in work processes which are based on modern IT technology - which is teleworking. Theoretically, it would seem that the diversity of the advantages of this flexible form of work does not lead to difficulties and dysfunction, but studies deny that.

The basic research method was the use of two separate forms of questionnaires and direct interviews, through which empirical material was collected, then subjected to scrutiny.

\section{Dysfunctions and pathologies in the communication process}

Dysfunction is defined as "... a phenomenon which affects in a negative way on a specific social system" (Pasieczny 2012, p. 118). Dysfunctions have the form of disorder, disturbance, abnormal activities or conditions that cause inefficiency in the functioning of the organization.

On the other hand the pathological phenomena in the organization we understand as actions (behavior) of individuals or groups contrary to the values of the culture of the organization. These activities are self-destructive or destructive to the community (see: Kozak 2009, p 14). Extending dysfunctional states leads to pathologies that threaten the viability of individual organizations. Pathology is a kind of disease of the organization.

The most frequently occurring dysfunctions in communication which may, in the long term, lead to pathological phenomena we include, among others (own development based on: Pophal 2001/2002, pp. 18-19):

- information distortion, resulting, inter alia, from the lack of precision (uniqueness and accuracy) of information transfer,

- providing chaotic and outdated information,

- the emergence of the information gapand therefore the lack of sufficient information to make a decision. It affects the rationality of decision making by: 
- limited amount of information sufficient to make a decision,

- reducing the number of solutions,

- possibility of no taking into account all alternatives and thus the omission of the most valuable,

- inadequate response to the situation,

- significant increase in the probability of not accepting the other decisions already taken,

- lack of feedback in the communication process,

- failure to provide time and space for discussion relevant to the issues involved according to a jointly agreed plan talks,

- lack of definition relevant to the achievement of the main objectives involved. It should be noted that the undirected (spontaneous) acts of communication itself does not contribute to solve the existing problems,

- lack of matching content and the method of communication to the audience,

- lack of consistency verbal level of communication with the non-verbal level. In the case when we deal with communication using the Internet, telephone, when there is no direct contact between human beings, there is still a problem with the lack of identification of the reaction and behavior of the sender of the transmitted message, which can greatly enable the transmission of false and falsified information,

- lack of or inability to formulate the main broadcast content in a concise, coherent and informative manner,

- lack of arrangements for the type of information of the order recipients (according to the hierarchy of functional),

- lack of definition of the relevant channels, forms and tools of communication,

- lack of desire to leave the initiative to communication, especially among managers who should know how to properly mobilize and encourage the cooperation of their subordinates,

- lack of skills in the construction of open communication and mutual trust,

- lack of ensuring an adequate level of redundancy of information through various channels and means of communication,

- providing information to unauthorized persons or activities aimed at blocking access to information.

Part of the above listed dysfunctions can arise unintentionally from the broadcasters, in turn, it can constitute a part of the symptom of their intentional action. Taking into account all these aspects it should be noted that on the one hand, the communication process ensures the functioning of the 
organization and has a real impact on the implemented processes within it, on the other hand it is determined by the same system of organization in which it is implemented.

\section{The results of empirical research on the identification of dysfunctions in communication in business organizations in the Southern Poland in the context of crisis}

To identify and describe the most common difficulties and dysfunctions in communication in organizations, there will be presented two studies carried out in the years 2010-2013.

The aim of the first study was to include making identification and diagnosis of a variety of tools and methods of communication that are used by entrepreneurs in the economic crisis.

The second study was conducted on teleworkers and employers employing telecommuters, and it had to show what difficulties and problems arise in the course of telecommuting, and then to be able to develop a methodology for minimizing and eliminating them.

Studies on the verification of how managers use different tools and methods of communication in conditions of economic crisis included a total of 226 people, of which $20 \%$ were employed in managerial positions, and $80 \%$ of them in executive management sphere

Both managers and employees of the executive management sphere argued that the economic crisis communication in their organizations was more intervention, ad hoc and spontaneous, rather than properly planned and organized. As many as $88.9 \%$ of the surveyed employees of companies indicated that their organizations had no communication plan related to the crisis.

Unfortunately, the study showed that in the South Polish enterprises (up 79.2\% of respondents) management did not take any measures to enhance the trust and cooperation between the company and co-workers, resulting in most often indicated the following disabilities:

- loss of confidence in senior management (109 responses),

- excessive suspiciousness towards co-workers (107 responses),

- fear of any acts of management (103 responses),

- resistance before engaging in any changes implemented in the organization (99 responses).

The study showed that internal communication in organizations that experienced a crisis was functioning as bad that it affected the significant 
deterioration of the atmosphere at work between employees (76.2\% of responses). Poorly organized crisis communication resulted in $71.6 \%$ in reduction of employee loyalty - the company. A similar effect can be seen in the relationship (including loyalty) employee - other employees. Faulty crisis communication has increased employee loyalty - other employees in only $5.8 \%$ of respondents, while decreased until $74.9 \%$ of cases. The crisis and the perceived deterioration in sentiment in companies, directly resulting from it, explicitly translated into a reduction of both employee loyalty to the company, as well as other associates, while increased mutual suspicion and lack of confidence to both the management as well as other people in companies. The study has resulted in several other regularities, namely $71.8 \%$ of the respondents indicated that the crisis has increased the number of conflicts (mostly conflicts between colleagues and their superiors) in their organizations, and $60.4 \%$ of the respondents indicated that their intensity increased at the same time.

Respondents presented (indications were confirmed as managers, too) that crisis communication in their organizations was very chaotic, no feedback in the communication process was often performed (54.6\% of responses). Respondents presented (indications were confirmed as managers, too) that crisis communication in their organizations was very chaotic, often performed the lack of feedback in the communication process (54.6\% of responses). Superiors are often not able to skillfully communicate relevant information to employees and executive staff indicated that there were often problems with the lack of matching the content and the method of communication to the audience and the manipulation of information and lack of consistency in a verbal level of communication with the non-verbal level, especially if it concerned information about the potential layoffs.

The indications that supervisors/managers could not honestly and objectively talk to their employees about the various problems and difficulties, which fell in their employing organization slide in the fore in this study. They do not listen to hints and suggestions of employees, even proceeded from the assumption that workers have to adapt to these adverse conditions in which they found each organization and strictly obey the commands issued.

4. The results of empirical research on the identification of dysfunction in communication in business organizations in the South Poland in context of the application of new IT technologies on the example of telework

The second study, which was conducted in 2013, aimed at diagnosing 
dysfunctional negative factors ${ }^{1}$ occurring in teleworking. A total of 172 surveys were collected and properly completed. Among the respondents women predominated slightly, 88 people, including 84 men. The survey was completed by 78 middle managers and senior managers.

Telework - a form of employment, which uses almost $100 \%$ all the technical innovations and new solutions of IT industry. In this case, the employees perform their work outside the office of the organization, most often at home, communicating with colleagues and their superiors, mainly through the Internet, e-mail and telephone. It appears in this case, a lot of new, negative factors that rarely or occasionally occur in the case of traditionally organized workplace.

The respondents indicated that working remotely makes them feel that higher responsibility than the traditional organized labor falls on them much - 128 indications, causing, among others, variety of negative emotions - 95 indications. Respondents indicated that the negative impact of telework on them is then causing excessive weakness and fatigue - 109 indications. In addition, 73 people indicated that they clearly feel that due to work as telecommuters they feel less useful for the employing company/organization, they feel that they have lower status and respectability in the community which may be the result of such erroneous belief that the work at home is "not work" - 92 indications.

As many as 55 respondents indicated that they suffer discrimination from management/supervisor, which manifests itself in, among others, lack of trust - 34 indications, excessive expectations - 23 indications, lack of objectivity in assessing -19 , and in claims and abuse in the approach to them - 15 indications.

The reason can also lie in the fact that teleworkers feel they are discriminated by co-workers - 43 indications. Teleworkers have complained about the lack of trust from colleagues - 27 indications, unwillingness to cooperate and blocking the ordered task which are necessary to perform and information - 23 indications, blaming responsibility for various errors or problems arising during the implementation - 21 indications, and disloyalty - 13 indications.

The analysis of responses to the question on loyalty associates (employees in the office) towards commuter can also confirmed that teleworkers may feel alone and rely mainly on themselves - 90 indications. Interesting conclusions can also

1 This specific study concerned the highlighting all the factors, that have de-humanizing effect on the teleworker. 
be inferred from analysis of the responses to the question on whether supervisors and co-workers create suitable atmosphere for work and commitment. Exactly half of the respondents 86 people indicated that they do not.

The loneliness of teleworkers and leaving their fate in their hands can also provide answers of representatives of companies and institutions who indicated that either at all or only as needed organize trainings designed exclusively for commuting - only 12 indications. As many as 91 respondents indicated that teleworkers are more productive than ordinary workers, and therefore can demand more from them and they just "abuse them". It has been also confirmed that there are problems with the appropriate coordination of work of teleworkers, as many as 80 respondents indicated the occurrence of such problems, perhaps due to the fact that supervisors / managers responsible for the work of teleworkers are not properly trained to perform such a role - 98 indications.

Dysfunctions and difficulties that relate to communication in traditionally structured organization, to a large extent, with redoubled force occurred in the case of this form of employment. Because of that telecommuters do not have direct contact "face to face" with their colleagues and superiors, it appeared the following communication problems that were raised by both telecommuters and representatives of organizations with remote workers:

- difficulties in precise transmission of very specific information and then interpreting them correctly,

- often due to the absence of teleworker in the office, having incomplete and outdated information,

- due to lack of sufficient information to make specific decisions, implementing a number of projects/initiatives incorrectly,

- lack of appearance of feedback in communication process, due to inter alia various technical problems with hardware and breaking the connection,

- difficulties in the capacity to provide time and space for discussion relevant to the issues involved, according to a jointly agreed plan of conversations, due to the lack of teleworker physically in the office and the need to adapt equipment and technical support for a particular meeting,

- lack of adequate communication skills by managers and supervisors to mobilize, encourage to engage in activities and therefore not being a coach/ mentor for the teleworker, the lack of ability to build open communication, which consequently leads to intensify the lack of mutual trust, so much important in working remotely.

Dysfunctions in communication in business

organizations in Southern Poland 


\section{Findings and conclusions}

The results of completed research inclined the authors to help reach a few basic conclusions in the context of dysfunction in communication in organizations:

1. Unfortunately, the organizations surveyed are planning something unpopular communication and communication procedures and streamline the flow of information, in presence of a variety of unforeseen events (such as the crisis), or in the context of the use of the knowledge of all employed people in the organization, including those who do not work directly in the organization. Communication between people is a rather ad hoc intervention, and therefore knowledge of employees may not be fully utilized.

2. Managers through communication are not trying to increase trust between management and employees (including those employed not physically in the office), which results in the different organizational dysfunctions, among them are: the fear of dismissal, excessive suspiciousness towards colleagues, fear of any action from the management, general embarrassment, and finally interpersonal conflicts.

3. It is also disadvantageous that incompetent organizing of meetings with all employees, the lack of adequate motivation to engage them in active transmission of the information and knowledge, lack of fairness and objectivity in the transmission of often manipulated information, and chaotic flow of information and knowledge between people, often not subjected to any verification and without power with new solutions and technical capabilities, significantly worsens, not improves the atmosphere in companies, reduces the employee-company loyalty and employee-other employees, and at the same time affects a significant reduction in confidence in the company and other persons and which worst increases the amount and intensity of internal conflicts in organizations, both between colleagues, as well, and those arising from employer-employee relationship.

Analyzing more widely the discussed issue it can be tempting to quote other studies that also confirm verified the accuracy of, and sometimes even wider indicate additional problems and deficiencies, which highlighted during the research ${ }^{2}$.

2 More in: Baruk 2009, pp. 53-57; Report: Internal Communications in Poland 2013 - between the challenges and constraints, http://www.proto.pl/raport_proto/info?itemId=127235, dated: 14/03/2014; Cewińska, Striker, Wojtaszczyk 2011, p. 469-485; Mikuła 2010, pp. 91-96. 
Apart from the usual problems associated with the lack of support by senior management colleagues and building through this open communication and willingness to cooperate, often demonstrated:

- low level of awareness of the importance of communication among senior executives,

- limited trust employees to communicate and managers, resulting from a large distance, which prevents the open sharing of information,

- lack of a clear internal communication strategy,

- the difficulty of measuring and reporting the results of work,

- organizational culture that is not conducive to building an open communication,

- lack of appropriate instruments of internal communication,

- problems in the area of employee satisfaction with work, affecting their attitude towards communication,

- lack of or improper involvement in the communication line managers,

- claiming attitude of the staff,

- in case of any trouble finding guilty ones and punish them in public immediately,

- bad organization of space to work, making it difficult to establishing contacts and communication,

- limited opportunities to develop expertise in internal communication. In order to improve the diagnosed defects it should be pointed out a few activities that properly applied can significantly improve the functioning of the organization, such as:

1. It is reasonable to organize frequent meetings with employees, during which it will be possible to transfer clear, understandable and most importantly not manipulated messages on planned activities.

2. The aim to improve the atmosphere in organizations by creating a good climate of cooperation and openness, especially in situations where dissemination of false information and rumors can be observed frequently which contributes to the spreading of excessive speculation and suspicion among employees.

3. It is reasonable to apply a transparent, clear and understandable messages, using for this purpose all available communication channels (including informal networks). The merits of use as far as possible and support the needs of new technical solutions, including specialized software, solutions to facilitate contact and synchronous and asynchronous communication should also be pointed out.

4. It is necessary to take care of the consistency of vision for change managers and employees, and continuous monitoring of the process. 
5. Managers should encourage and enable direct contacts between colleagues and encourage them to induce a sense of mutual trust - to enable and facilitate the flow of information between them.

6. Managers should care about employees feelings that they are needed in the organization to become more actively engaged in concrete action, finally to step up creatively to solve emerging problems, not under compulsion, but voluntarily, to feel "part" of the system/organization in which they are employed. This will be possible by creating a transparent and clear incentive systems, caring for staff development, enabling them to train and professional and personal development.

7. Legitimate and even it is necessary to use modern technical and technological solutions, streamlining and facilitating the transfer of all employees, filtering, receiving, analyzing information and knowledge, but it should be done, taking into account the specific situation of each organization, the conditions and circumstances on the market, finally opinions and thoughts on the matter of employees, including those not working physically in the office.

8. It is necessary to give relevant and reliable information to workers about actions taken and honest information about all the consequences of the planned changes, in order to minimize resistance and reluctance, always appearing among employees, which are often the result, just fear of the unknown.

9. That what we think, however, is the most important in any organization - is to build and cultivate solid organizational culture favoring open and kind internal communication. In this culture all employees of the organization should be identify, not only ordinary, but also senior management and managers who support in a systematic problem solving, they should give good examples to all employees.

Although the essence of communication with employees may seem selfevident, not always translate into practice - especially in today's dynamic market environment. The world is rapidly changing and the change has become a slogan for the company's focus, seeking growth opportunities. As a result, workers experience more frequent changes, causing confusion, skepticism and distrust that impedes the achievement of business objectives. This is why internal communication is more important today than ever before.

Efficient and effective communication both within the organization and its business environment is essential to its functioning. Increasing social mobility and the growing diversity of communication channels makes it necessary to adapt the already massively used in the enterprise IT infrastructure to the infrastructure and operation of a modern enterprise system. It is advisable to 
combine existing systems and tools, if you want to maximize resources, so as to avoid problems such as those related to loss of the worker in the jungle of information.

In summary it is clear that further improvements, especially in the field of technology, will increasingly affect the facilitation of communication between people but the communication process itself, is not nor will not dramatically change. It still will remain the sender and receiver, a specific channel, the technical interruptions will be more and more minimized with a growing and overwhelming and ubiquitous information noise feedback. Seemingly little has changed, but the technology is increasingly influencing on new technologies that do not necessarily have a positive effect on the man.

Communicating with people without physical intercourse with them has a wide, outside communication, social impact on organizational behavior of people at psychological, sociological and anthropological aspects which should be, especially in today's era, taken into account by managers and management organizations.

\section{Summary}

Dysfunctions in communication in business organizations in Southern Poland

In the study authors, on the basis of completed two different tests, pointed out the most common difficulties and dysfunctions in communication in contemporary organizations. Both traditionally functioning economic entities and organizations which employ teleworkers, where there is much more variety of problems, including due to lack of physical contact between people, were analyzed. In such situations a big impact on improving the process of information flow between people has modern technology and IT technology, which, however, has a negative impact on humans.

Keywords: communication, communication in organizations, dysfunctions and difficulties in the process of sending and receiving information.

\section{Streszczenie}

Dysfunkcje w komunikacji w organizacjach gospodarczych Polski Południowej

W opracowaniu autorzy wskazali na podstawie zrealizowanych dwóch różnych badań, jakie najczęściej występują utrudnienia 
i dysfunkcje w komunikacji we współczesnych organizacjach. Analizowano zarówno tradycyjnie funkcjonujące podmioty gospodarcze, jaki i organizacje zatrudniające pracowników zdalnych, w których występuje znacznie więcej różnorodnych problemów, m.in. z racji braku fizycznego kontaktu między ludźmi. W takich sytuacjach duży wpływ na usprawnienie procesu przepływu informacji pomiędzy ludźmi ma nowoczesna technika i technologia IT, która jednak wywiera także negatywny wpływ na człowieka.

\section{Słowa}

kluczowe: komunikacja, komunikowanie się w organizacjach, dysfunkcje i utrudnienia w procesie przesytania i odbioru informacji.

\section{References:}

1. Baruk A. (2009), Interpersonal relations in enterprises in times of crisis, "Economics and Organization of Enterprises", No. 6.

2. Cewińska J, Striker M., Wojtaszczyk K. (2011), Diagnosis and prevention of dysfunction in human resource management (Part I), in: Z. Janowska, Dysfunctions and pathologies in the field of human resource management, Publisher University of Lodz, Lodz.

3. Kozak S. (2009), Pathologies in the work environment. Prevention and treatment, Difin, Warszawa.

4. Mikuła B. (2010), Barriers processes of organizational learning in practice, in: Issues of Labour and Social Policy. Jubilee Book Dedicated to Professor Adam Szatkowski, University of Economics in Krakow, Krakow.

5. Pasieczny J. (2012), Pathologies of theorganization during the crisis, „Management and Finance - Journal of Management and Finance", No. 4.

6. Pophal L. (2001/2002), 10 Steps to Better Communication: Get Results with a Strategic Plan That Leaves Quick Fixes in the Dust, "Communication World", December-January, Vol. 19 (1).

7. Report: Internal Communications in Poland 2013 - between the challenges and constraints, http:/ / www.proto.pl/raport_proto/info?itemId=127235, dated: $14 / 03 / 2014$.

8. Stor M. (2002), Communicating in the organization, in: T. Listwan (ed.), Human Resources Management, Scientific Publishers C.H. Beck, Warszawa. 